\title{
Erratum to: Evolutionary dynamics of cycle length in pearl millet: the role of farmer's practices and gene flow
}

\author{
Ghayas Lakis · Athman Maï Ousmane - Douka Sanoussi - Abdoulaye Habibou • \\ Mahamane Badamassi • Françoise Lamy • Naino Jika • Ramatou Sidikou • \\ Toudou Adam · Aboubakry Sarr • Anne Luxereau • Thierry Robert
}

Published online: 14 March 2012

(C) Springer Science+Business Media B.V. 2012

\section{Erratum to: Genetica}

DOI 10.1007/s10709-012-9633-1

The original article has been published with typographical errors in the results section and the corresponding Tables. The true percentage of variation (\% var) explained by the village * landrace factor for the number of days between sowing and flowering of both main and last tillers is $2.3 \%$ and $3 \%$, respectively, rather than 7.4 and $6 \%$ as in the published article.

Additionally, the correct values of the degree of freedom ( $d f$ ) for the error terms in Table 8 should read as 286 for the Type I samples and 285 for the Type II samples.

The online version of the original article can be found under doi: 10.1007/s10709-012-9633-1.

G. Lakis $(\varangle)$ - F. Lamy · A. Sarr · T. Robert

Laboratoire Systématique et Evolution, UMR 8079, Université Paris-Sud, 91405 Orsay cedex, France

e-mail: ghayas.lakis@u-psud.fr

A. M. Ousmane · A. Habibou · T. Adam

Faculté d'Agronomie, Université Abdou Moumouni, Niamey,

Niger

D. Sanoussi - M. Badamassi $\cdot$ R. Sidikou

Faculté des Sciences, Université Abdou Moumouni, Niamey,

Niger

N. Jika

Institut National de la Recherche Agronomique du Niger,

Niamey, Niger

A. Sarr · T. Robert

Université Pierre et Marie Curie, 75005 Paris, France

A. Luxereau

CNRS-Muséum National d'Histoire Naturelle, Laboratoire

Eco-anthropologie-Ethnobiologie, Paris, France 